Original Article

\title{
MESUAFERRIN A-BIOACTIVE FLAVONOID ISOLATED FROM THE BARK OF MESUA FERREA L. AGAINST PHOSPHOLIPASE A2, CYCLOOXYGENASE AND LIPOXYGENASE: AN IN VITRO, IN VIVO AND IN SILICO APPROACH
}

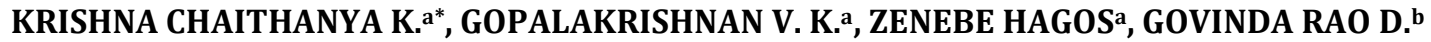

aDepartment of Chemistry, College of Natural and Computational Sciences, Aksum University, Axum, Ethiopia, bDepartment of Biochemistry and Molecular Biology, School of Biological Sciences, Central University of Kerala, India

Email: krishnachaitanyawc@gmail.com

Received: 13 Nov 2017 Revised and Accepted: 21 Dec 2017

\section{ABSTRACT}

Objective: The main objective of the present study was to evaluate the anti-inflammatory activity of isolated bioactive flavonoid Mesuaferrin-A from the bark of Mesuaferrea L. by in vitro, in vivo and in silico approach.

Methods: To evaluate the effect of isolated bioactive flavonoid Mesuaferrin-A on arachidonic acid metabolizing enzymes (PLA2, COX-2 and 5-LOX) using in vitro methods, followed by carrageenan-induced paw edema model by in vivo and to determine the binding orientation and interactions of Mesuaferrin-A onarachidonic acid metabolizing enzymes (PLA2, COX-2 and 5-LOX) crystal proteins using molecular docking (in silico) studies.

Results: Mesuaferrin-A exhibited a dose-dependent significant 5-LOX inhibitory and considerable COX-2 inhibitory activity by in vitro, The inhibitory activities of 5 -LOX and COX-2 at $100 \mu \mathrm{g} / \mathrm{ml}$ were found to be $78.67 \%, 81.03 \%$ with $\mathrm{IC}_{50}$ values of $45.22 \mu \mathrm{g} / \mathrm{ml}$ and $35.74 \mu \mathrm{g} / \mathrm{ml}$ respectively. Whereas Mesuaferrin-A showed less PLA 2 inhibitory activity. Mesuaferrin-A showed $68.34 \%$ inhibitory activity at 400 mg/kg body weight at the late phase of carrageenan-induced paw edema, and In silico studies demonstrated that Mesuaferrin-A strongly binds with 5-LOX and COX-2, these strong binding affinity of Mesuaferrin-A on active site amino acids of 5-LOX and COX-2 may be responsible for inhibition of enzyme activity. Mesuaferrin-A showeda comparable 5-LOX and COX-2 inhibition activity with (positive control)

Conclusion: It was concluded that Mesuaferrin-A act as 5-LOX and COX dual inhibitor, from the results it was suggests that Mesuaferrin-A, may be an effective preventive and therapeutic approach for patients with inflammatory-related diseases.

Keywords: Mesuaferrin-A, Phospholipase-A $\left(\mathrm{PLA}_{2}\right)$, 5-Lipooxygenase (5-LOX), Cyclooxygenase-2 (COX-2), Generic Evolutionary Method for molecular Docking (GEM Dock).

(C) 2018 The Authors. Published by Innovare Academic Sciences Pvt Ltd. This is an open access article under the CC BY license (http://creativecommons.org/licenses/by/4.0/) DOI: http://dx.doi.org/10.22159/ijpps.2018v10i2.23576

\section{INTRODUCTION}

Inflammation is an innate immune response activated by a variety of factors such as physical and chemical factors, immunological reactions, microbial infections, and tissue damage [1]. Its main functions are to protect the body against a wide variety of harmful agents and to promote the renewal of normal tissue. During inflammation up-regulation of inflammatory macrophages releases of pro-inflammatory mediators, such as nitric oxide (NO), prostaglandin E2 $\left(\mathrm{PGE}_{2}\right)$, and various cytokines, in response to activation signals, include chemical mediators, cytokines, and bacterial lipopolysaccharide (LPS) [2]. The inflammatory response in the host is important for interruption and resolution of the infectious diseases, but it is also often responsible for the signs and symptoms of the disease [3].

Arachidonic acid (AA) pathway is an important pathway in which phospholipase $\mathrm{A}_{2}\left(\mathrm{PLA}_{2}\right)$, cyclooxygenases (COXS) and lipoxygenase (LOX) and cytochrome P450 monooxygenases are act on phospholipids of membrane system and produce respective metabolites lysophospholipids, prostanoids, leukotrienes (LTs), hydroxyl eicosanoitetraic acids and epoxy eicosanoid tetraic acids are involved in normal and various pathophysiological functions [4]. Understanding the role of AA pathway in several inflammatoryrelated diseases, considerable efforts are being made to the discovery and development of inhibitors of AA pathway as inflammatory preventive and therapeutic agents. Non-steroid antiinflammatory drugs (NSAIDs) have been explored as chemo preventive agents for several cancers. Though, several side effects associated with usage of NSAIDs hindered their clinical applications. Therefore, naturally occurring anti-inflammatory agents with a high therapeutic index and less side-effects are required as substitutes for synthetic anti-inflammatory drugs. Mesua ferrea L. had been used as traditional medicine for treatment of inflammatory related diseases such as arthritis, leprosy and cancer. There are only few studies reported on anti-inflammatory activities of Mesua ferrea L. From the literature, phytochemical analysis of Mesua ferrea L. bark extract, showed the presence of secondary metabolites such as flavonoids, terpenoids, glycosides, steroids, quinones and coumarins [5]. Narendra Prasad et al., [6] reported that ethanolic leaf extract of Mesua ferrea L. has shown potent antioxidant activities (DPPH, ABTS and NBT). Pinkesh et al., [7] reported that in vivo carrageenaninduced rat paw edema is significantly inhibited by ethanolic extracts of Mesua ferrea L. flowers. No further work has been carried out on the isolated bioactive flavonoid Mesuaferrin A. Hence the present study was to evaluate the anti-inflammatory activity of isolated bioactive flavonoid Mesuaferrin-A by in vitro, in vivo and in silico approach for the development of novel therapeutic plant derived anti-inflammatory agents.

\section{MATERIALS AND METHODS}

Chemicals and materials

$\mathrm{PLA}_{2}$, and COX-2 kits from Cayman chemical company, Ann Arbor, Michigan, USA. 5-LOX from Invitrogen, USA. All other reagents used in this study were of analytical grade.

\section{Phospholipase A2 assay}

$\mathrm{PLA}_{2}$ assay was performed using $\mathrm{SPLA}_{2}$ enzyme inhibitory kit for assessing of anti-PLA $A_{2}$ activity of Mesuaferrin-A. This assay was performed as per the instructions of the manufacturer. The reaction mixture is a combination of $10 \mu \mathrm{l}$ of $\mathrm{PLA}_{2}, 25,50$ and $100 \mu \mathrm{g} / \mathrm{ml}$ of Mesuaferrin-A and $200 \mu \mathrm{l}$ substrate. The whole reaction mixture was 
incubated for $15 \mathrm{~min}$, after incubation, $10 \mu \mathrm{l}$ of 5, 5'-dithio-bis' 2nitrobenzoic acid (DTNB) was added to develop color and color is read at a wavelength of $415 \mathrm{~nm}$. After hydrolysis of the thioester bond at the $s n-2$ position of diheptanoylthio-Phosphatidyl Choline (PC) (substrate) by $\mathrm{PLA}_{2}$, the free thiols were detected using DTNB, which has an absorbance at $415 \mathrm{~nm}$. The control wells contain only $\mathrm{PLA}_{2}$, substrate and DTNB. Thioetheramide-PC was used as positive control. The percentage of inhibition of enzyme activity was calculated using the below formula.

$$
\% \text { Inhibition }=\left(\frac{\text { O. D. of control }- \text { O. D. of test }}{\text { O. D. of control }}\right) \times 100
$$

\section{Cyclooxygenase (cox-2) assay}

The COX-2 inhibitory assay was performed using a colorimetric COX-2 inhibitory assay kit for screening of COX-2 inhibitory activity of Mesuaferrin-A. This assay was performed according to the modified chromogenic method, using $\mathrm{N}, \mathrm{N}, \mathrm{N}, \mathrm{Nl}$-para tetra methylphenylenediamine (TMPD). Assay mixtures containing a COX-2 enzyme $(100 \mu \mathrm{g})$, hematin ( $15 \mathrm{mmol})$, EDTA ( $3 \mathrm{mmol}$ ) and 25,50 and $100 \mu \mathrm{g} / \mathrm{ml}$ of Mesuaferrin-A and $100 \mathrm{mmol}$ Tris HCL buffer $(\mathrm{pH}$ 8.0). The assay mixture was pre-incubated for $1 \mathrm{~min}$ at $25^{\circ} \mathrm{C}$. The Reaction is activated by adding a sufficient amount of substrate arachidonic acid and TMPD. TMPD is oxidized during the reduction of prostaglandin $\mathrm{G}_{2}$ to prostaglandin $\mathrm{H}_{2}$ by the activity of COX-2. The oxidation of TMPD represents the enzyme activity and measured at $603 \mathrm{~nm}$ using a spectrophotometer.

$$
\% \text { Inhibition }=\left(\frac{\text { O. D. of control }- \text { O. D. of test }}{\text { O. D. of control }}\right) \times 100
$$

\section{5-Lipoxygenase (5-LOX) inhibition assay}

The anti-inflammatory activity of Mesuaferrin-A was determined using in vitro 5-LOX inhibition assay. This assay analyses the inhibitory activity against the 5-LOX enzyme, which is involved in the synthesis of inflammatory mediators known as leukotrienes. This assay was first developed by [8], later it is modified by [9]. Lipoxygenases are a group of dioxygenases which are involved in the insertion of molecular oxygen into proinflammatory $\omega-6$ fatty acids such as arachidonic acid and linoleic acid. Leukotrienes are formed from the initial attack on arachidonic acid by 5 -lipoxygenase which adds molecular oxygen to carbon 5, leading to the formation of hydroperoxyeicosatetraenoic acid (5-HPETE), dehydration of 5HPETE gives the epoxide, these epoxides then undergoes isomerisation of their double bonds and gives leukotriene A4 (LTA4). Hydrolysis of LTA4 leads to the formation of stable LTB4.

Linoleic acid is used as a substrate for the determination of 5-LOX enzyme inhibition assay because it shares a structural resemblance with arachidonic acid [10]. The increase in absorbance at $234 \mathrm{~nm}$ is due to the formation of 1,3-diene from 1, 4-diene in linoleic acid hydroperoxide which is used in the determination of 5-lipoxygenase inhibitory assay.

Mesuaferrin- $A$ is tested at different concentrations viz., 25, 50 and $100 \mu \mathrm{g} / \mathrm{ml}$. The activity of 5 -Lipoxygenase was compared with the standard positive control Zileuton.

The percentage inhibition of 5-lipoxygenase inhibitory activity of Mesuaferrin-A was calculated by using a formula.

$$
\text { Percentage of tnhtbition }=\left(\frac{O D \text { af control }-O D \text { of test }}{O D \text { of control }}\right) \times 100
$$

\section{Assessment of anti-inflammatory activity}

For screening and assessment of anti-inflammatory compounds, carrageenan-induced paw edema is widely used animal model for acute inflammation and was introduced by [11]. Carrageenan is a mucopolysaccharide, derived from Iris sea moss, produce nonimmunological edema. There are two phases of carrageenaninduced inflammatory reactions, i.e. Initial phase and late phase. The initial phase (1-3h) involves the release of histamine, serotonin and kinins from mast cells responsible for swelling and pain [12]. During the late phase (4-5 h) two important inflammatory mediators such as prostaglandin $\mathrm{E}_{2}\left(\mathrm{PGE}_{2}\right)$ and leukotriene $\mathrm{B} 4$ are synthesized from arachidonic acid-dependent pathways by cyclooxygenase-2 (COX-2) and 5-lipoxygenase (5-LOX) enzymatic system involved with the commencement of inflammatory reactions.

\section{Anti-inflammatory effect of Mesuaferrin-A on carrageenan- induced inflammation in Wistar rats}

Carrageenan-induced paw edema used for the evaluation of the antiinflammatory activity. Male Wistar albino rats weighing 160-180 g were obtained from M/s Mahavir Enterprises (Hyderabad, Andhra Pradesh, India). The animals were fed with standard laboratory diet, which was purchased from M/s Rayan's Biotechnology Pvt. Ltd. (Hyderabad, Andhra Pradesh, India) during the experiment the rats were fed with water and food adlibitum. Animal experiments were conducted according to CPCSEA guidelines. The Animal experimental protocol was approved by the Institutional Animal Ethical Committee (IAEC) of GITAM University (IAEC no. 517/ IAEC/ 2012).

The animals were divided into four groups each group containing six animals $(n=6)$. The first group was given normal saline by intragastric catheter tube (IGC), the second, and third groups (200 and $400 \mathrm{mg} / \mathrm{kg}$ body weight) received the Mesuaferrin-A isolated bioactive flavonoid for $10 \mathrm{~d}$ and the forth group received diclofenac sodium as a standard ( $10 \mathrm{mg} / \mathrm{kg}$ body weight). The paw volume was measured plethysommetrically (ug obasile, Italy) at $0 \mathrm{~h}, 1 \mathrm{~h}, 2 \mathrm{~h}, 3 \mathrm{~h}$, $4 \mathrm{~h}$, and $5 \mathrm{~h}$ after the injection of carrageenan. The percentage of inhibition of paw volume of treated groups was calculated by comparing with a mean paw volume of the control group.

$$
\text { Pernantage inhihitim }=\left(\frac{\text { Control paw volumo }- \text { Tast paw volume }}{\text { Control yaw volume }}\right) \times 1 \mathrm{co}
$$

\section{Molecular docking studies of mesuaferrin-A on 5-LOX I GEM dock}

The X-Ray crystal structure of protein 5-lipoxygenase (PDB ID: 308Y), COX-2 (PDB ID: 4COX) and PLA 2 (PDB: 1DB5) used in docking studies were retrieved from Protein Data Bank. Co-crystallized ligands and water molecules were removed from target protein using Argus lab. Ligands are prepared using chemoffice (Cambridge). Energy minimization was done using molecular mechanics. The minimization was executed by the root mean square value reached below $0.001 \mathrm{Kcal} / \mathrm{mol}$. Such energy minimized ligands and receptors were used for docking studies using GEMDOCK (Generic Evolutionary Method for molecular docking). A population size of 300 with 70 generations and 3 solutions were used in docking accuracy setting. Pymolis used for better visualization of the interactions.

\section{Statistical analysis}

The results were expressed as the mean \pm Standard error of the mean (SEM). The statistical difference between the test and control groups were evaluated by one-way analysis of variance (ANOVA) by Graph pad prism 6.0 software and followed by Dunnett's t-test.* $p \leq 0.05$, ${ }^{* *} \mathrm{p} \leq 0.01,{ }^{* * *} \mathrm{p} \leq 0.001$ represents a significant difference between the control with the test group.

\section{RESULTS AND DISCUSSION}

In general the processes of wound heal occurring in the body with the lapse of time is the greatest gift of nature mother to mankind. During this process, the body responds/reflects this process through different modes such as pain, swelling, raised temperature and erythema. In order to reduce the incidence of this process, allopathic doctors prescribe anti-inflammatory drugs called NSAIDs (NonSteroidal Anti-Inflammatory Drugs). Although these drugs provide temporary relief, research data suggests that it could give undesirable side effects such as gastric ulceration, liver damage and even stimulates the likelihood of getting myocardial infarction and stroke [13]. In this case, natural anti-inflammatory compounds are of immense interest and have been used to mediate the antiinflammatory process often with lesser side effects [14].

\section{Effect of mesuaferrin-A on PLA 2 activity}

Mesuaferrin-A was evaluated for PLA 2 inhibitory activity with different doses viz., 25,50 and $100 \mu \mathrm{g} / \mathrm{ml}$ as per the manufacturer's 
directions. As shown in fig. 1the inhibitory effect of Mesuaferrin-A was found to be increased concentration-dependent manner. The percent inhibition was observed to be $15.38,24.49$ and $41.23 \%$ respectively. However, the inhibitory effect of Mesuaferrin-A was

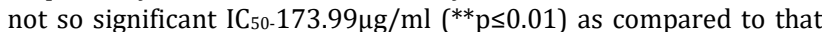
of Thio etheramide-PC whose $\mathrm{IC}_{50}$ was $6.65 \mathrm{\mu g} / \mathrm{ml}$. Our results also correlated with Apigenin-7-O-B-D-Glucuronide Methyl Ester Isolated from ethyl acetate of Manilkarazapota leaves have significant inhibitory effects on spla 2 activity [15].

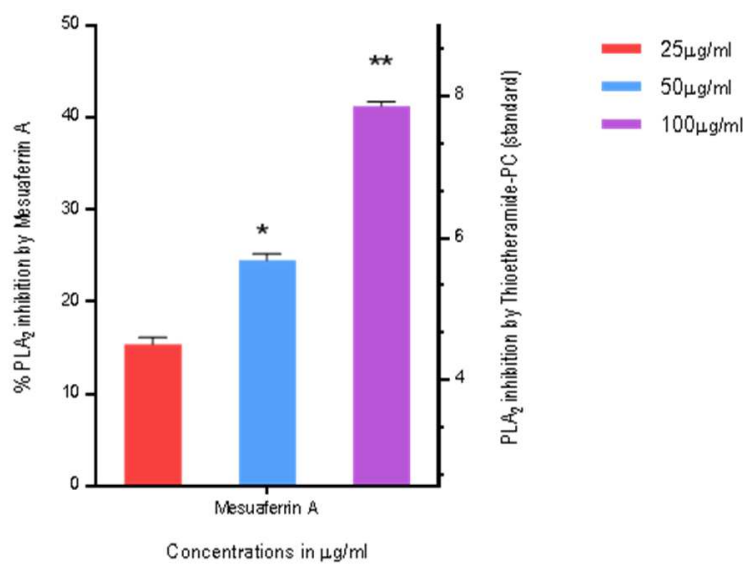

Fig. 1: Inhibitory effect of Mesuaferrin-A against $P_{L} A_{2}$ activity compared with, Thioether amide-PC standard. Values are mean of three replicates \pm SEM. ${ }^{*} \mathbf{p} \leq 0.05,{ }^{* *} \mathbf{p} \leq 0.01,{ }^{* * *} \mathrm{p} \leq 0.001$ represents a significant difference compared with the Thioetheramide-PC $(5 \mu \mathrm{g} / \mathrm{ml})$

\section{Effect of mesuaferrin-A on COX-2 activity}

Mesuaferrin- $A$ was tested on COX-2 activity by taking different doses viz., 25,50 and $100 \mu \mathrm{g} / \mathrm{ml}$ and corresponding percentage inhibition obtained was found to be $29.12,52.98$ and $78.67 \%$ respectively. As shown in fig. 2 a dose-dependent percentage inhibition of COX-2 activity was observed at $100 \mu \mathrm{g} / \mathrm{ml}$ was found to be $78.67 \%$ with $\mathrm{IC}_{50}$ value of $45.22 \mu \mathrm{g} / \mathrm{ml},\left({ }^{* *} \mathrm{p} \leq 0.001\right)$ while that of Diclofenac was found to be $3.78 \mu \mathrm{g} / \mathrm{ml}$.

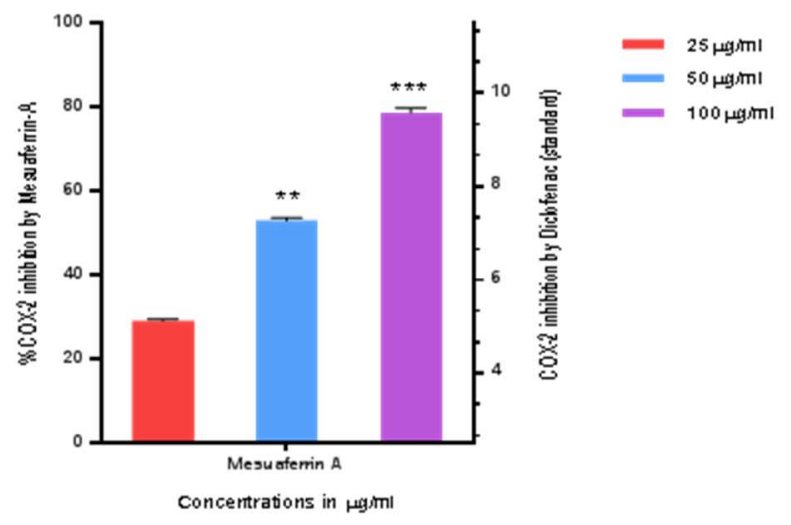

Fig. 2: Inhibitory Effect of Mesuaferrin-A against COX-2 activity compared with, Diclofenac sodium. Values are mean of three replicates \pm SEM. ${ }^{*} \mathbf{p} \leq 0.05,{ }^{* *} \mathbf{p} \leq 0.01,{ }^{* * *} \mathrm{p} \leq 0.001$ represents a significant difference compared with the Diclofenac sodium $(5 \mu \mathrm{g} / \mathrm{ml})$

Hong et al. [16] found that curcumin inhibited AA metabolism by blocking the phosphorylation of $\mathrm{CPLA}_{2}$, down-regulating of COX-2 expression and inhibiting the 5-LOX catalytic activity. Caoet al., [17] also reported that Senkyunolide 0 and cryptotanshinone were isolated from Ligusticumchuangxiiong and Salvia miltiorrhiza exhibited selective COX2 inhibitors with IC 50 values of 5 and $22 \mu \mathrm{M}$, respectively.

\section{Effect of mesuaferrin-A on 5-LOX activity}

The Mesuaferrin-A was tested for 5-LOX inhibitory activity by taking different doses viz., 25,50 and $100 \mu \mathrm{g} / \mathrm{ml}$ as shown in fig. 3,a significant dose-dependent percentage inhibition of 5-LOX activity was observed at $100 \mu \mathrm{g} / \mathrm{ml}$ was found to be $81.03 \%$ with IC $\mathrm{I}_{50}$ value of $35.74 \mu \mathrm{g} / \mathrm{ml}, \quad\left({ }^{* *} \mathrm{p} \leq 0.001\right)$, while that of standard inhibitor zileuton whose $\mathrm{IC}_{50}$ value was $5.09 \mu \mathrm{g} / \mathrm{ml}$.

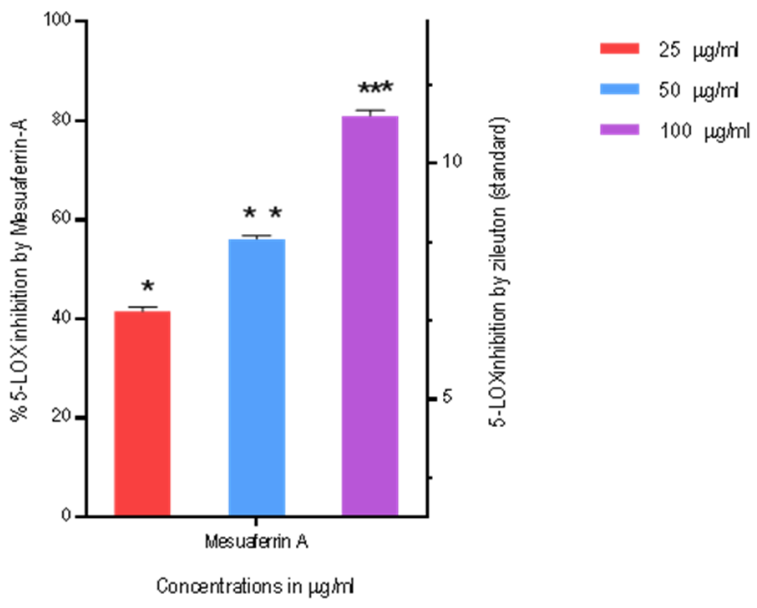

Fig. 3: Inhibitory Effect of Mesuaferrin-A against 5-LOX activity, values are mean of three replicates \pm SEM. ${ }^{*} p \leq 0.05,{ }^{* *} p \leq 0.01$, ${ }^{* * *} \mathbf{p} \leq \mathbf{0 . 0 0 1}$ represents significant difference compared with the zileuton $(5 \mu \mathrm{g} / \mathrm{ml})$

The anti-inflammatory activity of Mesuaferrin-A is possible due to inhibition of pro-inflammatory enzymes. Han et al. [18] reported that Garcinol, a polyisoprenylated benzophenone have to possess 5LOX inhibitory activity and suppressive effect on LTB4 production in cancer cells. Our results also correlated with that the bacteria associated with $H$. amboinensis having anti-inflammatory to inhibit the COX-1, COX-2, and sPLA2 enzymes activity. Yosie et al., [19]

Anti-inflammatory effect of mesuaferrin-A on carrageenaninduced acute inflammation in wistar rats

It is well known that carrageenan-induced paw edema is characterized by biphasic event with the involvement of different inflammatory mediators. The results of the present investigations revealed that the flavonoid fraction isolated from the stem bark of Mesuaferra L. Possess significant anti-inflammatory activity against acute inflammatory models carrageenan-induced paw edema.

As shown in the fig. 4, the isolated bioactive flavonoid Mesuaferrin-A (200 and $400 \mathrm{mg} / \mathrm{kg}$ body weight) showed $42.31 \%\left({ }^{*} \mathrm{p} \leq 0.05\right)$ and 53.52 $\%\left({ }^{* * *} \mathrm{p} \leq 0.001\right)$ and $57.36 \%\left({ }^{* *} \mathrm{p} \leq 0.01\right)$ and $68.34 \%\left({ }^{* * *} \mathrm{p} \leq 0.001\right)$ paw edema inhibition at $4^{\text {th }} \mathrm{h}$ and $5^{\text {th }} \mathrm{h}$ respectively, whereas Diclofenac $(10$ $\mathrm{mg} / \mathrm{kg}$ body weight) showed $75.59 \%\left({ }^{* *} \mathrm{p} \leq 0.01\right), 82.70 \%\left(^{* * *} \mathrm{p} \leq 0.001\right)$ edema inhibition at $4^{\text {th }} h$ and $5^{\text {th }} h$ respectively. Hence it can be concluded that Mesuaferrin-A has shown potent anti-inflammatory activity comparable to standard drug Diclofenac in both early and late phases. Muralidhar et al., [20] reported that the flavonoid fraction isolated from the stem bark of Buteaonosperma significantly reduced the inflammation in the carrageenan-induced rat paw edema and cotton pellet induced granuloma in rats. Ishwar Bhat and Abhishek kumar [21] also reported that synthetic novel 1,5 benzodiazepine derivatives having antiinflammatory activities against carrageenan-induced paw edema in rats.

It was known that levels of COX-2 and 5-LOX are more in $4^{\text {th }}$ to $5^{\text {th }} \mathrm{h}$, of the second phase of acute inflammation. This demonstrated that in vivo anti-inflammatory activity of Mesuaferrin-A probably due to COX-2 and 5-LOX inhibition. 


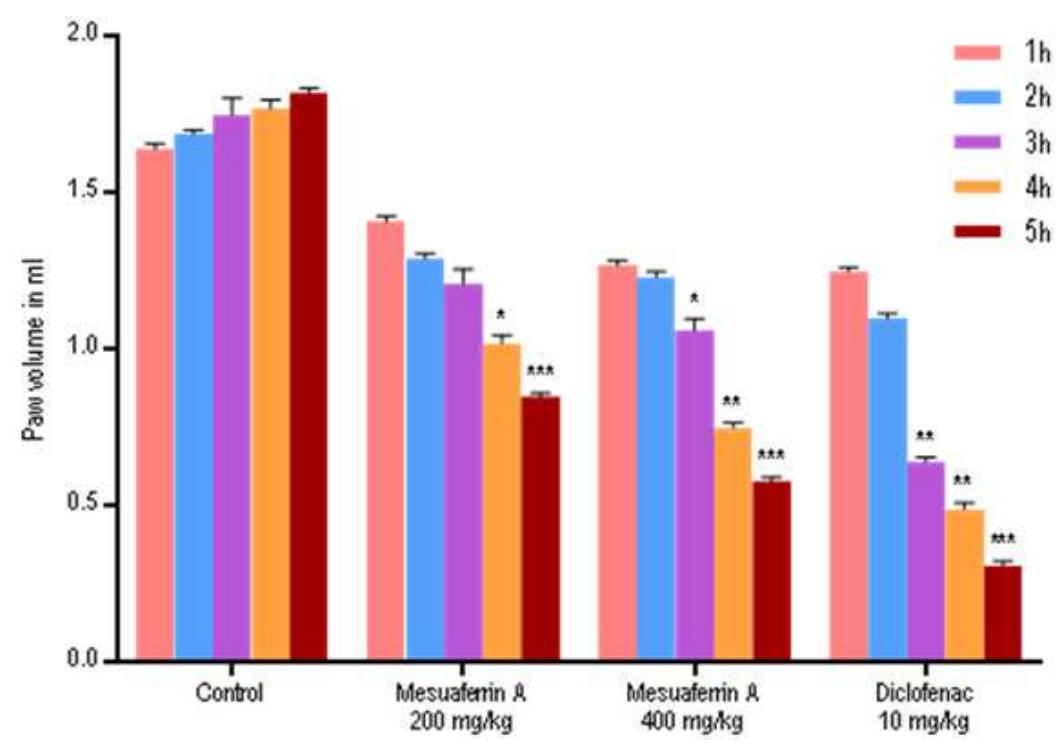

Fig. 4: Inhibitory effect of Mesuaferrin-A on carrageenan-induced paw volume $(\mathrm{ml})$ in Wistar rats, values are mean of three replicates \pm SEM. ${ }^{*} \leq 0.05,{ }^{* *} \mathbf{p} \leq 0.01,{ }^{* * *} \mathbf{p} \leq 0.001$ represents significant difference compared with the Diclofenac (10 mg/kg body weight)

Molecular docking studies (in silico) of isolated mesuaferrin-A on PLA2, 5-LOX and COX-2 crystal proteins

Molecular docking studies demonstrated that Mesuaferrin-A showed good binding affinity on 5-LOX crystal protein with binding energy of$158.67 / \mathrm{mol}$ and binds in the vicinity of amino acid residues (fig. 5). Mesuaferrin-A binds on PLA 2 and COX-2 crystal protein with binding energies-115.49 and-136.77 respectively. In silico studies validated

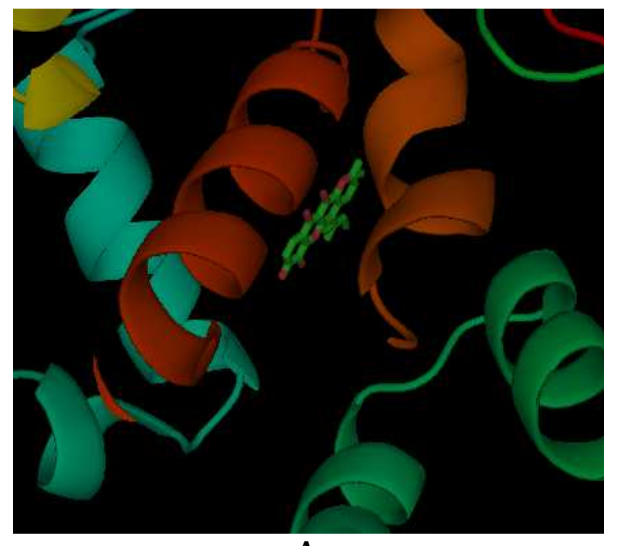

A that Mesuaferrin-Astrongly binds with 5-LOX and COX-2, the strong binding affinity of Mesuaferrin-Aon active site amino acids of 5-LOX and COX may be responsible for inhibition of enzyme activity.

From the above studies, it is quite apparent that the flavonoid fraction of Mesuaferrin-A isolated from Mesua ferra L. stem bark possesses significant anti-inflammatory activity by inhibiting Cyclooxygenase-2 and 5-Lipoxygenase inflammatory enzymes.

Fig. 5: Molecular docking studies of mesuaferrin-A on 5-LOX crystal protein, A. Binding orientation of mesuaferrin-A on 5-LOX crystal protein. B. Interactions of mesuaferrin-A with amino acid residues of 5-LOX

\section{CONCLUSION}

The isolated bioactive falvanoid Mesuaferrin-A from Mesuaferrea $\mathrm{L}$. bark ethyl acetate extract acts as a dual inhibitor by inhibiting 5LOX, COX-2 enzymes and inhibiting carrageenan-induced paw edema in the late phase. Mesuaferrin-A exhibited comparable antiinflammatory activity with standard inflammatory drugs. Hence, it can be concluded that to development of novel plant-derived antiinflammatory drugs without having side effects.

\section{ACKNOWLEDGMENT}

I am very happy to convey my sincere thanks to esteemed Professor U. S. N Murthy, Chief Scientist, Head, Department of Biology, Indian Institute of Chemical Technology, and Hyderabad, India has permitted me to carry out pharmacological studies in his laboratory.

\section{FINANCIAL SUPPORT}

This work was partially supported by UGC-MRP. F. No. 4N 2643/2013, New Delhi, India sanctioned to Prof. Duddukuri Govinda Rao, GITAM University, Visakhapatnam.

\section{AUTHORS CONTRIBUTIONS}

Corresponding author (Dr. K. Krishna Chaithanya) contributed in performing the experiment and writing of the manuscript, Dr. V. K. Gopalakrishnan has contributed to compilations of the manuscript, Mr. Zenebe Hagos has contributed for statistical analysis and Dr. D. Govinda Rao has contributed in experiment design and valuable guidance to Krishna Chaithanya for his Ph. D research work.

\section{CONFLICT OF INTERESTS}

The author(s) declare(s) that there is no conflict of interest. 


\section{REFERENCES}

1. Hong $\mathrm{YH}, \mathrm{Chao} \mathrm{WW}$, Chen ML, Lin BF. Ethyl acetate extracts of alfalfa (Medicago sativa L.) sprouts inhibit lipopolysaccharideinduced inflammation in vitro and in vivo. J Biomed Sci 2009; 16:64-75.

2. Fujiwara N, Kobayashi K. Macrophages in inflammation. Curr Drug Targets Inflamm Allergy 2005;4:281-6.

3. Medzhitov R. Origin and physiological roles of inflammation. Nature 2008;454:428-35.

4. Nagendra Sastry Y, Anupam B, Gautam S, Reddanna P, Arunasree MK, Dhananjaya BL, et al. Targeting arachidonic acid pathway by natural products for cancer prevention and therapy. Semin Cancer Biol 2016;40-41:48-81.

5. Krishna Chaithanya K, Kamalakararao K, Sastry YN, Padal SB, Rajyalakshmi A, Govinda Rao D. Anti-Inflammatory, antioxidant and phytochemical analysis of Mesuaferrea bark extracts. Int J Curr Trends Pharm Res 2015;3:891-902.

6. Narender Prasad D, Ganga Rao B, Sambasiva Rao E, Mallikarjuna Rao T, Praneeth VS. Quantification of phytochemical constituents and in vitro antioxidant activity of Mesuaferrea leaves. Asian Pacific J Trop Biomed 2012;56:S539-S542.

7. Pinkesh KT, Irchhaiya R, Jain SK. Evaluation of the anticonvulsant activity of Mesuaferrea Linn. ethanolic flower extract. Int J Pharm Life Sci 2012;3:1507-9.

8. Sircar JC, Schwender CF, Johnson EA. Soy-bean lipoxygenase inhibition by non-steroidal anti-inflammatory drugs. Protaglandins 1983;25:393-6.

9. Reddanna P, Rao MK, Reddy CC. Inhibition of 5-lipoxygenase by vitamin E. FEBS Lett 1985;193:39-43.

10. Baylac S, Racine P. Inhibition of 5-lipoxygenase by essential oils and other natural fragrant extracts. Int J Aromather 2003;13:138-42.

11. Winter CA, Risley EA, Nuss GW. Carrageenan-induced paw edema in hind paw of the rat as an assay for anti-inflammatory drugs. Proc Soc Exp Biol Med 1962;111:544-54.

12. Vinegar R, Scheiber W, Hugo R. Biphasic development of carrageenan edema in rat. J Pharmacol Exp Ther 1969;166:96-103.
13. Beg S, Swain S, Hasan H, Barkat MA, Hussain MS. Systematic review of herbals as potential anti-inflammatory agents: recent advances, current clinical status and future perspectives. Pharmacogn Rev 2011;5:120-37.

14. Reynolds JF, Noakes TD, Schwellnus MP, Windt A, Bowerbank P. Non-steroidal anti-inflammatory drugs fail to enhance healing of acute hamstring injuries treated with physiotherapy. South Afr Med J 1995;85:517-22.

15. Kamalakararao K, Krishna Chaithanya K, Gopalakrishnan VK, Zenebe Hagos, Kalayu MA, Patricia PN, et al. Apigenin-7-O-B-Dglucuronide methyl ester isolated from Manilkarazapota leaves. Int J Pharm Quality Assurance 2017;8:58-65.

16. Hong J, Bose M, Ju J, Ryu JH, Chen X, Sang S, et al. Modulation of arachidonic acid metabolism by curcumin and related betadiketone derivatives: effects on cytosolic phospholipase A2, cyclooxygenase and 5-lipooxygenase. Carcinogenesis 2004;25: 1671-9.

17. Cao H, Yu R, Choi Y, Ma ZZ, Zhang H, Xiang W, et al. Discovery of cyclooxygenase inhibitors from medicinal plants used to treat inflammation. Pharmacol Res 2010;61:519-24.

18. Han CM, Zhou XY, Cao J, Zhang XY, Chen X. Dihydroxy groups are critical for the anticancer effects. Garcinol Bioorg Chem 2015;60:123-9.

19. Yosie A, Leni M, Habsah M, Hermansyah A, Siti Aisha MR, Jasnizat S. Anti-inflammatory activity of bacteria associated with a marine sponge (Haliclonaamboinensis) via reducing NO production and inhibiting cyclooxygenase-1, cyclooxygenase-2, and secretory phospholipase A2 activities. Asian J Pharm Clin Res 2017;10:95-100.

20. Muralidhar A, Sudhakar Babu K, Ravi Sankar T, Reddanna P, Reddy GV, Latha J. Anti-inflammatory activity of flavonoid fraction isolated from the stem bark of Buteaonosperma (LAM): a mechanism based study. Int J Phytopharmacol 2010;1:124-32.

21. Ishwar Bhat $K$, Abhishek Kumar. Synthesis and antiinflammatory activity of some novel 1, 5 benzodiazepine derivatives. Asian J Pharm Clin Res 2016;9:63-6. 